\title{
FORMATION OF THE CIVIL NATION IN RUSSIA: DYNAMICS FROM LOCAL TO ALL-RUSSIAN FORM OF IDENTITY
}

\author{
V. Akaev \\ Comprehensive research institute of Russian Academy of Science \\ Grozny, Russian Federation \\ science-almanac@mail.ru
}

The formation features of the Russian civil nation are seen as a strengthening factor of the multinational Russian people unity, defined in the Russian Constitution as a carrier of sovereignty and the only source of power. The problematization of the interethnic relations improvement in the country at the present stage is actualized by the need for theoretical understanding of the possibility creating "the Russian nation law" in Russia. This issue has debatable, ambiguous nature; many national researchers are against the development and adoption of such a law. Opinions are expressed that in the national state policy, the improvement of interethnic relations in Russia, the resource of economic, political, cultural development of the multinational Russian people is not over. Many things in the nations and nationalities development, solid formation of local and ethnic, regional values, forms of identity should be realized in various regions of the country. There is a multi-level character of the all-Russian identity, which should be taken into consideration in the course of its formation. The development of the all-Russian identity as the foundation for the Russian civil nation formation is represented on the basis of strengthening, development of such ethno-cultural diversity.

Key words: ethnos, ethnic identity, all-Russian identity, nation, civil political nation, law and nations.

[Акаев В.X. Формирование гражданской нации В России: динамика от локальноэтнической до общероссийской формы идентичности]

Рассматриваются особенности формирования российской гражданской нации как фактора укрепления единства многонационального российского народа, определенного в Конституции России в качестве носителя суверенитета и единственного источника власти. Проблематизация совершенствования межнациональных отношений в стране на современным этапе актуализируется необходимостью теоретического осмысления возможности создания в России «закона о российской нации». Данный вопрос приобрел дискуссионный, неоднозначной характер, многие отечественные исследователи выступают против разработки и принятия такого закона. Высказывается мнение о том, что в государственной национальной политике, совершенствовании межнациональных отношений в России ресурс экономического, политического, культурного развития многонационального российского народа не исчерпан. Многое предстоит сделать в плане развития наций и народностей в различных регионах страны, прочного формирования у них локально-этнических, региональных ценностей, форм идентичностей. Отмечается наличие многоуровнего характера общероссийской идентичности, которая должна учитываться в ходе ее формирования. На базе укрепления, развития такого этнокультурного многообразия представляется развитие общероссийской идентичности как основы фрормирования российской гражданской нации.

Ключевые слова: этнос, этническая идентичность, общероссийская идентичность, нация, гражданская политическая нация, закон и нации.

VakhitKh. Akaev - Ph.D. of philosophy, professor. Chief scientific worker of Comprehensive research institute of Russian academy of science, academician of Academy of science in Chechen Republic, expert of Russian academy of science. Grozny, Russian Federation.

АкаевВахитХумидович - докторфилософрскихнаук, профрессор. Главный научный сотрудник КНИИ PAН, академик АН ЧР, эксперт РАН. г. Грозный, Россия. 
To date there is no uniform position in interpretation of maintenance of the concept "civil nation" among scientists and politicians of Russia. Moreover, there is no definite answer to the question: can the multinational Russian people be recognized as a civil nation? If so, what is its essence, if not, what is the mechanism of its formation? The formation of a civil nation is not so much an artificial process of its construction as a primordial process, but also politically controlled by the state, which implements its control functions. And on this way, from our point of view, it is important to preserve local, ethnic, religious values, to strengthen the conditions for the existence of all the peoples of the country, and on the whole to determine the mechanism for developing a specific system for its formation. This process should be associated with a thorough achievement of ethnic identity, and then it is aimed at the formation of an all-Russian identity, as the most important dynamics of the formation and development of each nation, ethnic group.

Content aspects of the concepts of "ethnic identity", "all-Russian identity", "identity of the Russian nation" is important explanation in theoretical and methodological terms. Ethnic identity is the recognition by the ethnophore or ethnos of its place in the world, relations to other peoples, power, the general socio-cultural values guiding its development within the framework of a single state. But a higher level of identity is the all-Russian identity, it involves the assimilation of values associated with their feelings, moods, and knowledge associated with the awareness of the essence of the motherland, co-citizenship. L.M. Drobizheva determined that "the identity of the civic nation is the sense of belonging to the Russian state, the people, the idea of the country, territory, ethnic diversity, these are our symbols and values, language and culture, the bygone dramas and achievements, it is the readiness to go and fight for our common interests" [2]. In her recent studies she claims that "all-Russian identity is understood by us as identifying ourselves with citizens of the country and state-territorial space" [3, p. 27]. All-Russian identity, in her opinion, is a multi-component phenomenon and includes state and territorial, country, historical and cultural identity [3, p. 27]. It seems that through the formation of such a form of identity, considering its multi-level nature, the successful formation of the Russian civil nation is possible.

Is there a civil nation in Russia today? The concept of "multinational Russian people" fixes in the Constitution of the country [4, p.3]. But the content of these concepts do not match. On the other hand, in the "Strategy of State National Policy", adopted in 2012, the task of strengthening Russian civil identity is set[9]. What does it mean for every Russian citizen, who has this or that nationality, belonging to the "multinational Russian people" as a "bearer of sovereignty and the only source of power" [4, p. 3].

Some Russian researchers claim that there is a civil nation in Russia, an ethnologist, academician V.A. Tishkov thinks so. He argues that the people living in the country can be fully justified as a multi-ethnic civil nation [11, p. 5], but other researchers have an alternative position, believing that its formation has not been completed. The same opinion has R.G. Abdulatipov, sociologist, academician of RAS M.K. Gorshkov. L.M. Drobizheva considers so, the specific sociological studies carried out by her, from our point of view, they are aimed at establishing the limits of the possibility of creating the concept of the Russian political nation.

If the identity of the multinational Russian nation and the civil identity are identical, then we can assume that we have a Russian civil nation. But, if a civil nation understands how it is understood in the West, for example, in the US, then our situation will be different. There is no multinational people in the US, but there is a people interpreted as a political nation. Also there are German, French, Italian, Spanish, British political nations. Russia is a multinational state, which can not be said about the United States. As a state and civilization Russia united many ethnic groups, nations with their territories, customs, traditions, 
languages, cultures, the vast majority of which, being part of Russia, were preserved and developed.

In this meaning it is noteworthy to quote the Russian philosopher I. Ilyin «Don't eradicate, suppress, enslave others' blood, don't strangle a foreign and heterodox life, but give everyone breathing and a great homeland, all observe, all people try on, give everyone a chance to pray in their own way, work in their own way and best from everywhere to involve in the state and cultural building" [Quot. from: 7].

What kind of Russia should be and how to solve the national question, it is better than this statement of I.llyin is difficult to find. From his point of view, Russia is not a stepmother, but mother, Homeland for all peoples, which holds together, integrates them on the basis of common values, which is fundamentally important today in national-state construction. It means that the relationship between the state and its nation must have the character of a bilateral movement, not unilateral. The state should take care of all its peoples, take care of their cultures, lifestyle, contributing to their successful socioeconomic and spiritual-cultural development. At the same time, the peoples of Russia are obliged to express a high level of patriotism, civic consciousness, readiness to uphold the national interests of the country, which should be their ideological and vital principle [6]. It's obviously, there is a successful development of Russian identity, Russian civil identity, as the basis for the formation of a political nation in our country. But nevertheless, a lot of things should be done.

There are a few considerations about the multi-structure or multilevel Russian identity. This quality is clearly visible in various subjects of Russia, especially in the republics. Thus, the formation of civil identity in Dagestan is represented on the basis of the following multi-level identity scheme: Family -Tukhumna- Jamaat - Ethnic - All-Dagestan - Caucasian - All-Russian. According to this scheme - Family -Tayipovskaya-TukhumnayaCaucasian - all-Russian - the identity of the Chechens is forming. Such a multi-level identity scheme can also be found in Tatars, Bashkirs, Chuvashes, as well as among other Russian nations, taking into account their local, ethnic, confessional features, their awareness of themselves as representatives of a certain kind, region, ethnic group, nation and citizens of a single country. In this hierarchy of identities, kinship, clan and ethnocommunal ties are strong enough, which must be taken into account in the process of the formation of the all-Russian identity, and consequently also of citizenship. This allows us to recognize that local-regional-ethnic features form the basis of group solidarity, reaching it, self-consciousness of each nation and nation is formed and on this path the formation of the all-Russian national consciousness is taking place.

It is also important to note that socioeconomic factors - limited resources, security, lack of professional prospects, a sharp social stratification of society, alienation of power and the people negatively influence the formation of the Russian political nation. Professor M.I. Bilalov finds out another aspect that obstracts the formation of civil society, the civil nation in Russia. These are the guidelines for Western liberal-democratic civil societies of the classical type that are inappropriate to our peoples because of the peculiarities of mentality, the traditional material and spiritual order [1].

In scientific literature there is a position according to which the formation of a civic national identity is proposed to start with common Russian values: The earlier mastering of the Russian language, the history and culture of the Russian nation, the study of heroes of various wars, etc. The implementation of this line leads to certain metamorphoses in practice. For example, in a strange way there is a reduction in the teaching of the ethnoregional component in the schools of the republics, it means the teaching of native languages and literatures, regional geographies and histories.

Meanwhile, the process of forming an all-Russian identity does not begin immediately, because it comes from the concrete, the particular, the specific to the common. 
Accounting for this natural dialectical process is very important for modern nations and peoples of the country, where local, special, ethnic, religious forms of identity are sufficiently entrenched, fundamental, manifesting themselves in ethno-cultures and mentalpsychological characteristics of peoples. Undoubtedly, they form the basis for the formation of a common Russian identity. This correlation should be taken into account in the process of the formation of the civil nation, in the implementation of the state national policy in the country $[12 ; 13]$.

Russian philosopher Vladimir Soloviev raised the question: what is Russia? Thinking about it, another domestic thinker, L.A. Tikhomirov brought this matter to the question of the ways of a better life for its peoples, which best corresponds to its internal structure, determined, though to some extent, by the psychology of the tribe or tribes that entered it. To understand this inner being is a question of the greatest importance for each country $[10$, p. 257]. But this question is not only abstract, theoretical, but it has both obvious practical significance and various solutions, Tikhomirov wrote, which gives completely different directions to both Russia's foreign and domestic policies [10, p. 258]. These thoughts, expressed 100 years ago, are no less relevant than in the past for us contemporaries. As it seems to us, the formation and development of the civil nation is not a walk along the smooth NevskyProspekt. This process is based on an understanding of the essence of the self-consciousness of nations, united in a single multinational Russian people, the constituent parts of which have developed ethnic cultures, their historical territories, languages, and mental features. These parameters form the basis of their national identity. What are parameters of self-consciousness of the Russian civil nation? Are the concepts of "multinational Russian people" and "Russian civil nation" identical? These are questions of theory and practice. Russia is a multiethnic country, but is multinationalism reduced to polyethnicity? In the same case, it turns out that the multinational Russian people are a separate Russian nation as a "nation of nations".

In order to accelerate the process of forming the Russian civil nation, a point of view is expressed about the need to adopt a law on the Russian nation and the management of inter-ethnic relations. At the Interethnic Relations Council meeting in Astrakhan, which was held on October 25, 2016, this idea was expressed, and the president of the country, V.V. Putin approved it.Meanwhile, the formation of a nation is a process of centuries-old natural-historical at the same time and politico-legal, state-administrative, based on real phenomena that should be successfully used in the course of its formation. When they say, it is necessary to create a federal law, the question arises, but is the carriage put beforethe horse? And a certain persistence to accelerate formation of the Russian nation sounds like slightly of forcible constructivism which, since 90th years, is imposed to political ethnology, public opinion of Russians. It was then that in the early 2000s, a limited circle of intellectuals exposed to liberal democratic values, as the ideal society where the US solved the national question, was seen by the United States, and therefore offered to "forget the nations," to perform "requiem for ethnics", burned with an ardent desire to urgently mobilize Power and society for the construction of the "Russian nation". Meanwhile, the current foreign policy realities show that this state can not be an ideal for imitation in the solution of the national question.

There is another aspect. We believe that domestic scientists should carry out research on overcoming the existing terminological disagreement associated with the interpretation of the concepts "multinational Russian people", "Russian nation", "Russian civil nation", "multi-ethnic Russian nation", etc. Thus, the need to implement theoretical and methodological activities is problematized, and the modern conceptualization of the national policy pursued in the country acquires "a new breath". Thus, in the Russian Academy of Sciences scientists have developed a vocabulary of terms, basic concepts that will be used to prepare a draft law, conditionally called the "law on the Russian nation." It de- 
fines the Russian nation as "a civil-political community, consolidated on the basis of historical statehood, whose members have equal rights regardless of ethnic, racial and religious affiliation, common historical and cultural values, a sense of belonging to a single people, civic responsibility and solidarity " [5]. From our point of view, the attempt to define the "Russian nation" is the most important theoretical task and on the correctness of its solution depends the success of scientific research, as well as practical actions in the field of national policies in the country.

In the definition of scientists of the Russian Academy of Sciences, the "Russian nation" is defined through a civil-political community, but this is not explained, but recognition of its consolidation on the basis of historical statehood is problematic, what are common historical and cultural values is also not clear. There is no certainty that today the country has developed a sense of belonging to a single people. At the end of the definition being analyzed, such signs as "civil responsibility and solidarity" are added. What is the need for this, it is not clear, because in the beginning of the definition the concept of "civil-political community" is used, does it not take into account the signs of "civil responsibility", "solidarity"? It is thought that so. Therefore, the proposed definition of the Russian nation is internally contradictory, and in strictly scientific terms cannot be accepted as a correct definition of the concept of "Russian nation".

Of course, we could not agree more that today in Russia we need a formula on the basis of which national unity should be achieved based on respect for the identity of all the peoples inhabiting the country. Any attempt to reverse this very identity is fraught with serious consequences. In this regard, we believe that, comprehending problems of the international relations in modern Russia it is impossible to ignore ethnic, folk origin. The practice of national policy in the country cannot fail to take into account the real processes associated with complex objective intra-political, intra-ethnic, inter-confessional relations and migration processes, sometimes determining their aggravation. At the same time, it is important to take into account both foreign policy and geopolitical problems that are foiling the country's domestic policy. Studying the private, special and general aspects of the marked relationships, their interrelationship is the most important scientific and theoretical task. It is considered that the decision will be effective:

1 ) by combining the efforts of researchers from different regions of the country, studying interethnic relations, suggesting ways to improve them;

2) at thorough theoretical study of the major state documents concerning problems of national policy to eliminate terminological discrepancies;

3 ) if an Expert Commission is established at the state level to bring the documents reflecting the national policy of Russia into terminology;

4) taking into account the contradictory nature of the process of formation of the national consciousness of Russians in a multinational Russian state, we consider it necessary to work out a Concept for strengthening the unity of the multinational Russian people as a key conceptual position based on the unity of ethnocultural, ethnopolitical and civic values.

Summing up, it should be noted that today the issue of preserving the ethnopolitical and ethno-cultural diversity of the country, strengthening the unity of the multinational Russian people is topical. On this basis it seems to be implementation of complex measures, and as a whole, strategies for countering anti-state, anti-Russian forces, trying to split, split the unity of diversity Russia. In conclusion, I would like to quote R.G. Abdulatipova, that has a deep meaning: "The preservation of identity and the integration of diversity in the unity of socio-political interests is the essence of the formation of the Russian nation, which is reflected in the ethno-national and civil identity of Russians" [8, p. 471]. 
1. Билалов М.И. Через призму единства и многообразия // Дагестанская правда. 2017. 15 марта.

2. Выступление Л.М. Дробижевой на Заседание Совета по межнациональным отношениям. 31 октября 2016 года. г. Астрахань // http://kremlin.ru/events/president/news/53173

3. Дробижева Л.М. Общероссийская идентичность и уровень межнационального согласия как отражение вектора консолидационных процессов // Социологические исследования. 2017. № 1.

4. Конституция Российской Федерации. М., 1993.

5. Крецул Р. Российской нации дали определение // Известия. 2017, 20 апреля.

6. Несмеянов Е.Е., Колосова О.Ю. Информационная культура в контексте глобальных процессов // Гуманитарные и социально-экономические науки. 2014. № 3 .

7. Путин Владимир. Россия: национальный вопрос // Независимая газета. 2012. 23 января.

8. Российская нация (этнонациональная и гражданская идентичность россиян в современных условиях). М., 2005.

9. Стратегия государственной национальной политики Российской Федерации // http://kremlin.ru/events/president/news/15635

10. Тихомиров Л.А. Что такое Россия? // Русская идея: Сборник произведения русских мыслителей. М., 2002.

11. Тишков В.А. Российский народ: история и смысл национального осмысления. M., 2013.

12. AkayevV.H.Islamin modern Russia: interrelation of traditions and innovations // HaучныйальманахстранПричерноморья. 2015. № 3. http://science-almanac.ru

13. Akaev V.Ethnocultural diversity and consolidation of Caucasus people unity: theoretic-methodologic analysis //НаучныйальманахстранПричерноморья. 2016. № 3. http://science-almanac.ru

14. Nesmeyanov E.E., Rudenko A.M., Kotlyarova V.V.Sociocultural analysis of cyberterrorism in social nets within the problems of information safety of Russian society // НаучныйальманахстранПричерноморья. 2015. № 4. http://science-almanac.ru

\section{References}

1. Bilalov M. Through the prism of unity and diversity//Dagestanskayapravda. 2017. March 15.

2. The statement by L. M. Drobizheva at the Council's meeting on Inter-Community Relations. October 31, $2016 . \quad$ Astrakhan//http://kremlin.ru/events/president/news/53173

3. Drobizheva L. All-Russian identity and the level of inter-ethnic harmony as a reflection of the vector of consolidation processes// Sociological research. 2017. No 1.

4. Constitution of the Russian Federation. M., 1993.

5. Kretsul R. The Russian nation has given a definition//Izvestiya. 2017, April 20.

6. Nesmeyanov E.E., KolosovaO.Yu. Information culture in the context of global processes // Humanities and socio-economic sciences. 2014. No 3.

7. Putin Vladimir. Russia: nationality question // Nezavisimayagazeta. 2012. January 23.

8. Russian nation (ethnic and civil identity of Russians in modern conditions). M., 2005. 
9. The Strategy of the State National Policy of the Russian Federation // http://kremlin.ru/events/president/news/15635

10. Tihomirov L. What is Russia? //The Russian idea: Collection of works of Russian thinkers. M., 2002.

11. Tishkov $V$. The Russian nation: history and meaning of national understanding. M., 2013.

12. Akayev V.H. Islam in modern Russia: interrelation of traditions and innovations // Sciencealmanac of the Black Sea region countries. 2015. No 3. http://sciencealmanac.ru

13. Akaev V.Ethnocultural diversity and consolidation of Caucasus people unity: theoretic-methodologic analysis // Sciencealmanac of the Black Sea region countries. 2016. No 3. http://science-almanac.ru

14. Nesmeyanov E.E., Rudenko A.M., Kotlyarova V.V.Sociocultural analysis of cyberterrorism in social nets within the problems of information safety of Russian society // Sciencealmanac of the Black Sea region countries. 2015. No 4. http://sciencealmanac.ru 